\title{
Implementation of Sharing \& Jumping Tasks Learning to Foster Students' Creative Thinking Skills in Buffer Solution
}

Witty Zestia*, Asep Supriatna, Nahadi

Postgraduate Chemistry Education Master Program, Indonesian University of Education, Bandung, 40154

\section{ARTICLE INFO}

\section{Article history:}

Received: 27 July 2021

Revised: 05 Jan 2022

Accepted: 12 Jan 2022

Published online: 24 Jan 2022

\section{Keywords:}

Creative Thinking Skills

Buffer Solution

Sharing \& Jumping Tasks

\begin{abstract}
A B S T R A C T
This study aims to identify the growth of students' creative thinking skills in the implementation of learning sharing \& jumping tasks in the buffer solution material. The method used in this research is descriptive qualitative. The research was conducted in one of Bandung's high school students of class XI with a total of 24 students. The instruments used for data collection were interview guidelines, audio and video recordings through zoom meetings and observation sheets. The collected data were analyzed based on Transcript Based Lesson Analysis (TBLA). The results showed that in the sharing task all aspects of creative thinking skills emerged during the learning process, namely in the aspects of fluent thinking, flexible thinking, original thinking, elaborative thinking, and evaluative thinking. Meanwhile, in the jumping task, there is one aspect that does not appear, namely the aspect of original thinking.
\end{abstract}

\section{Introduction}

In accordance with the demands of life in the 21 st century where people can master various skills in facing and preparing for future challenges. Likewise, 21st century learning that focuses on innovation skills and higher order thinking skills. (Wijaya et al., 2016) states that the demands of the 21st century are student learning abilities and skills which include critical thinking, problem solving, creative, innovative, able to communicate and collaborate. One of the 21 st century skills that can be developed through learning chemistry is creative thinking skills (Hadzigeorgiou et al., 2012). Creative thinking skills are mental processes used by individuals to come up with new ideas, new insights, new approaches, new perspectives and new ways. to understand various things (Birgili, 2015; Eragamreddy, 2013; Forrester et al., 2008). Creative thinking will bring out creativity and make students have many ways to solve problems with different perceptions and concepts (Kutlu \& Gökdere, 2015; Risnawati \& Saadi, 2017).

\footnotetext{
${ }^{*}$ Corresponding author. 
Based on the results of observations made on buffer solution learning in class XI in one of the high schools in Bandung, it shows that the learning process is still conventional, namely by using lecture and question and answer methods. In the learning process through zoom meetings, the teacher uses powerpoint media to explain the buffer solution material. In the learning process, the teacher acts only as a provider of information to students, and during the learning process, not even if students ask the teacher when the teacher explains the buffer solution material, students only give answers if the teacher asks when the teacher explains. From the observation results, it is shown that learning does not explore students' creative thinking skills on the material being studied, students' cognitive and reasoning abilities are difficult to develop. This is in line with the opinion (Potur \& Barkul, 2009) which states that creative thinking is an original cognitive ability and problem solving process. Students involve all their thinking skills to find a way to the solution of a problem at hand.

And based on the results of teacher interviews, it was found that the learning objectives focused more on the ability of students' mathematical concepts in calculating the $\mathrm{pH}$ of a buffer solution than on students' chemical concepts to find and prove themselves the buffer solutions that are commonly found in everyday life. To train students' ability to calculate the $\mathrm{pH}$ of a buffer solution, the teacher gives more practice questions so that students get used to doing chemical calculations. It can be concluded that learning does not contribute to efforts to grow students' creative thinking skills. Learning activities are more oriented to the basic competencies of the cognitive domain than the basic competencies of the psychomotor domain, namely how students are able to complete tasks and calculate the $\mathrm{pH}$ of a buffer solution, not how students perform in constructing the concept of a buffer solution. In learning the teacher still applies the old paradigm to the dimensions of cognitive processes, only focusing on doing the exercises, without giving students the opportunity to think creatively as a result, students do not find the meaning of what they learn. In this case, the teacher's learning still relies on six processes, namely: memory, understanding, application, analysis, synthesis, and evaluation. (Amabile et al., 1996; Northcott, n.d.) stated that creative thinking is related to knowledge, motivation, finding problems, finding new ideas or ideas, and evaluation. Furthermore, the learning method used has not been able to grow students' ability to think creatively.

Creativity is a person's ability to give birth to something new, either in the form of ideas or real works, either in the form of new works or in combination with things that already exist, which has never existed before by emphasizing the ability that is related to the ability to combine, solve or answer problems, and reflect creative children's operational abilities. According to (Sternberg, 2003) a creative person is someone who can think synthetically, meaning that he can see relationships where other people are not able to see who has the ability to analyze his own ideas and evaluate the value or quality of his personal work, able to translate theories and abstract things into practical ideas, so that individuals are able to convince others of the ideas they will work on. Creative thinking as a general ability to create something new, as the ability to provide new ideas that can be applied in problem solving, or as the ability to see new relationships between pre-existing elements 
(Munandar, 1999). (Krulik \& Rudnick, 1995) explained that creative thinking is thinking that is original, reflective, and produces a complex product. To measure creative thinking skills in this study, indicators are used according to (Munandar, 1992).

Here are presented aspects of creative thinking skills (Munandar, 1992) along with the details of each indicator: 1 . Fluency, with indicators: a. Generating many ideas, answers, problem solving or answers, b. Provide many ways or suggestions for doing various things, c. Always think of more than one answer. 2. Flexibility, with indicators: a. Generating various ideas, answers or questions, b. Can see the problem from a different point of view, c. Looking for many alternatives or different directions, d. Able to change the way of approach or thinking. 3. Originality, with indicators: a. Able to give birth to new and unique expressions, b. Thinking of unusual ways to express oneself, d. Able to make unusual combinations of parts or elements. 4. Elaboration, with indicators: a. Able to enrich and develop an idea or product, b. Add or detail the details of an object, idea or situation so that it becomes more interesting. 5. Evaluation, with indicators: a. Determine the benchmark for self-assessment and determine whether a statement is true, a healthy plan or a wise action, b. Able to make decisions on open situations, c. Don't just come up with ideas but implement them. Research that examines creative thinking skills can be seen from the research: (Aldig \& Arseven, 2017; Basarmak, 2019; Cenberci, 2018; Damayanti \& Sumardi, 2018; Habibi et al., 2020; Kacan, 2015; Koray \& Köksal, 2009; Kumdang et al., 2018; Perdana \& Rudibyani, 2020; Rahardjanto, 2019; Rajović et al., 2017; Sriwongchai et al., 2015; Syahrin et al., 2019; Tandiseru, 2015). These studies examine the effect of applying various models and learning methods on students' creative thinking skills. These studies aim to examine and develop students' creative thinking skills as a result of learning by using quantitative and qualitative research methods.

Creative thinking skills can be developed by collaborative learning. As revealed by (Widiarta et al., 2017) that collaborative learning is indicated to have a contribution in increasing students' creative thinking skills, and students who have good competence, it will be easier to develop creative thinking skills. (Sato, 2014) suggests that collaborative learning is not only beneficial for students with low and moderate academic abilities, but collaborative learning can also guarantee students with high academic abilities to become even better. (Johnson \& Johnson, 1991) states that during the collaborative learning process, students can share learning materials and support each other to achieve common learning goals. Collaborative learning is actually a learning method that emphasizes more on specific tasks and sharing tasks in group work, comparing conclusions and group work procedures, and giving students greater flexibility in group work (Dillenbourg, 1999). In collaborative learning, learning strategies are applied with a number of students as members of the study group and each member of the group must work together actively to achieve the goals that have been determined in an activity with a certain structure so that it becomes a meaningful learning process (Barkley et al., 2014). 
In learning activities involve various students' abilities to understand. Therefore, the learning process uses two types of tasks, namely sharing tasks, namely individual tasks through collaboration in small groups that contain basic material and material that refers to learning objectives. In addition to sharing tasks, there is also a jumping task that contains problems that aim to improve students' abilities. The problem given the jump task is the development and application of material concepts (Sato, 2014). In learning, sharing tasks and jumping tasks will provide benefits for all students, both students with low cognitive abilities and students with high cognitive abilities and also improve affective and psychomotor abilities (Cahyani, 2017). Based on the explanation above, the researchers conducted a study that aims to identify the growth of students' creative thinking skills in the implementation of sharing learning \& jumping tasks in the buffer solution.

\section{Methodology}

The method used in this research is descriptive qualitative research method. The research was conducted by implementing learning sharing \& jumping tasks in one of the high schools in Bandung to the class XI students, totaling 24 students. The instruments used in this study were audio and video recordings using zoom meetings and observation sheets. Learning analysis was carried out based on Transcript Based Lesson Analysis (TBLA). TBLA aims to investigate the characteristics of learning (Arani, 2017). Analysis of students' creative thinking skills using creative thinking indicators (Munandar, 1992).

\section{Results and Discussion}

The learning process consists of two activities, namely sharing task and jumping task. Sharing task activities aim to facilitate students so that students can work together, care for each other, and share knowledge with each other in completing tasks given by the teacher. By sharing tasks, it can help students who do not understand the material to ask for help from students who already understand. Thus, a meaningful teaching and learning process will be created, having high values and enthusiasm for learning so that learning objectives can be achieved properly. In accordance with the instructions of the minister of education and culture, to break the chain of the spread of COVID-19, learning in schools is carried out by applying Distance Learning, for that learning is carried out using the Zoom Meeting application where students are divided into groups in breakout zoom.

In the sharing task activity, students in groups are given the task of identifying and proving the nature of the buffer solution through practicum with tools and materials that are around. Then students complete the tasks in the LKPD related to the practicum that has been done. Furthermore, in the jumping task activity, the tasks given are applicable, where students are given the task of finding examples of the role of buffer solutions in everyday life and their components. The learning process at each stage of learning activities and the results of the analysis of 
students' creative thinking skills based on Transcript Based Lesson Analysis (TBLA) which refers to the indicators of creative thinking (Munandar, 1992), can be described as follows:

\section{Sharing Task Activities}

In preparation for learning, students are grouped into 7 groups with each group consisting of 2-4 students. Each group consists of students who have different abilities, namely high, medium, and low. This is done so that the discussion can run well, there is a sharing process between students in completing the tasks given by the teacher. Each group consists of students who have different abilities, namely high, medium, and low. This is done so that the discussion can run well, there is a sharing process between students in completing the tasks given by the teacher.
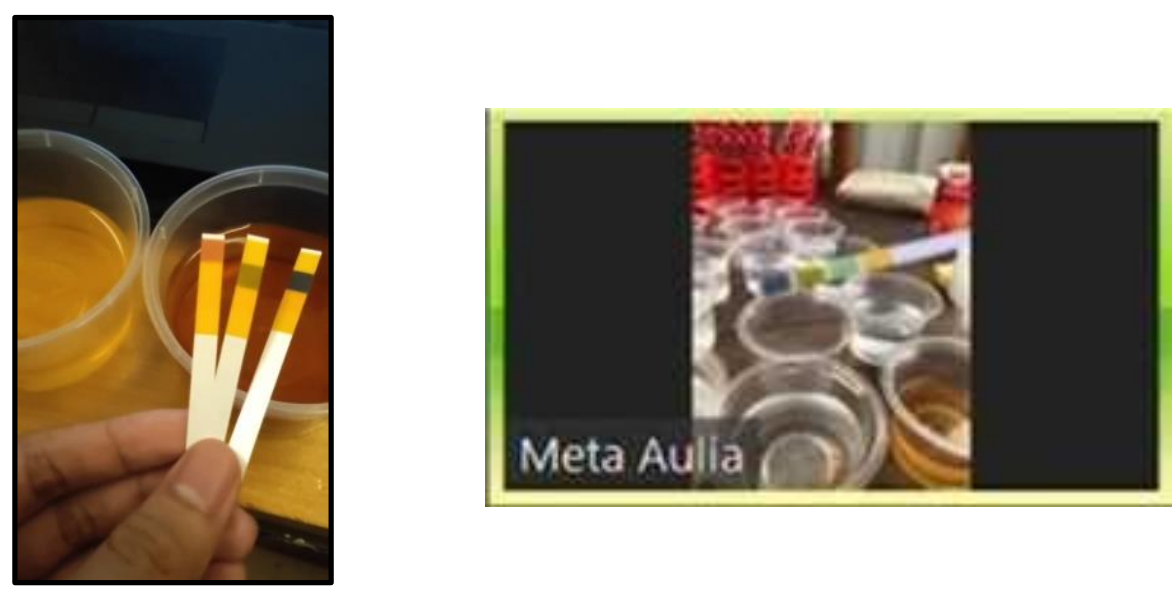

Figure 1. Students Carry Out Experiments on sharing

The teacher divides students according to groups that have been assigned to breakout zoom for task sharing activities. In the sharing task activity, the teacher gives the task to each group to identify and prove the buffer solution through practicum using materials that are around in accordance with the tasks in the LKPD. Each student conducts an online experiment through a zoom meeting and completes assignments in the LKPD and presentations with an allotted time of 45 minutes. And in this activity, each student prepares tools and materials and conducts discussions and practicums according to the tasks given. The task given is that students design and conduct experiments to determine whether some of the materials that have been prepared are buffer solutions or not. The tools and materials used in the experiment are tools and materials that are around, which are easy to find at home or in a shop and are not dangerous, because there are some ingredients that are also used as cooking spices, drinks and medicines. Furthermore, students complete the tasks in the LKPD related to the practicum that has been carried out and present the results of their group discussions. The following is a graph that shows the percentage of creative thinking skills in task sharing activities. 
Graph of the percentage of students' creative thinking skills in sharing task activities

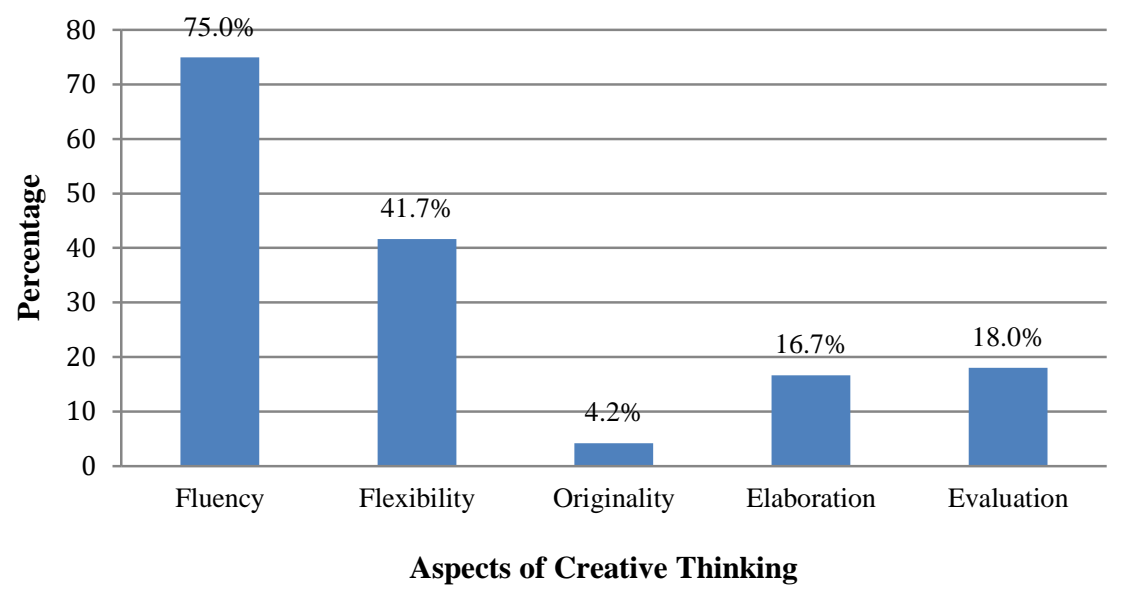

Figure 2. Graph of the Percentage of Students' Creative Thinking Skills in Sharing Task Activities

In Figure 2, it can be seen that the students' creative thinking skills activity from the data of the entire group (there were 7 groups) showed that 5 aspects of creative thinking were identified during the sharing task activity. These aspects include the fluency aspect with the highest percentage of $75 \%$, the aspect of flexibility with the percentage of $41.7 \%$, the originality aspect with the lowest percentage of $4,2 \%$, the elaboration aspect with the percentage of $16.7 \%$, and the evaluation aspect with the percentage of $18.0 \%$.

Based on the identification results of the sharing task activities, it can beexplained that students' creative thinking skills grow in all aspects of creative thinking skills according to the indicators and sub-indicators that appear during the learning process. Learning activities that foster students' creative thinking skills occur through the thinking process: designing experiments, conducting experiments, collecting data and drawing conclusions based on experimental data. Based on the graph with a percentage of $75 \%$, which shows more than half of the number of students who show creative thinking skills in the fluency aspect. This shows that students have been able to think fluently, generate thoughts with many ideas and provide suggestions in the learning process. In completing assignments, there are some students who seek and find working procedures or experimental steps through books, searching through the internet and then discussing what they get with their group mates. Even so, the discussion that students do is a good thing, because with students discussing, students can express ideas, thought, and provide suggestions in completing the given task so that it is easy to understand. Thus, it can be concluded that students have the ability to think creatively smoothly through discussion by expressing ideas, thought, and providing suggestions in solving problems/tasks.

Furthermore, from the graph above it can be seen that students have flexible thinking skills with a percentage of $41.7 \%$. This happens because some students 
are less able to distinguish acid and base compounds. The difficulty of students in thinking flexibly to classify things into different categories, because students still experience confusion in understanding materials that are acidic or basic compounds, it can be said that there is still a lack of knowledge of students' prerequisites about acid or base acid compounds.

In the aspect of originality with a percentage of only $14.2 \%$, it shows the low level of students in mastering creative thinking skills in the aspect of originality. This shows that original thinking skills are still difficult for students in learning, students are used to seeing learning resources, from books, and searching the internet so that students are not accustomed to developing ideas and thought in learning. This is evident from the experimental design made by students when learning takes place, not much different from books or the internet with the sentence structure not much different. This shows that students are less confident with the results of their own thoughts so that students go back to looking at books or the internet to look for the same answer to feel more confident with the experimental design they made. Students look for similarities with books to strengthen their confidence in the correctness of the experimental design they have made.

In the elaboration aspect with a percentage of $16.7 \%$, it can be seen that only a small number of students can detail the objectives, tools and materials, make experimental procedures, observation tables, and conclusions. This shows that students have understood in making an experimental procedure, although in designing practicum procedures students are still looking for and finding it from books and the internet. However, it supports in developing students' creative thinking skills in the elaborative aspect and students are trained to detail answers by doing detailed things such as designing experimental procedures. In the evaluation aspect, from the graph it can be seen that the percentage of students' evaluative thinking abilities is $18 \%$. This can be seen when students discuss the experimental design, how students discuss the appropriate experimental design, provide an assessment of the experimental design that will be used in the experiment.

\section{Jumping Task Activities}

Jumping task is a jump task in the form of an applicative task from the basic concepts that have been developed. According to (Hendayana \& Hidayat, 2013), the jumping task is to provide students with higher level problems to improve the abilities of higher students. In the jumping task activity, students are assigned to look for examples of the role of buffer solutions in everyday life and components of buffer solutions with an allotted time of 25 minutes. Examples of the role of buffer solutions in everyday life and components of buffer solutions are the main buffer system in the intracellular fluid in the fluid outside the cells (blood), in the pharmaceutical industry, in the food industry, waste treatment, and so on. These examples are very close in everyday life, so this learning can provide students with an understanding of the concept of a buffer solution in contextual life. And it 
is hoped that with the achievement of this jumping task, the learning objectives can be achieved well.

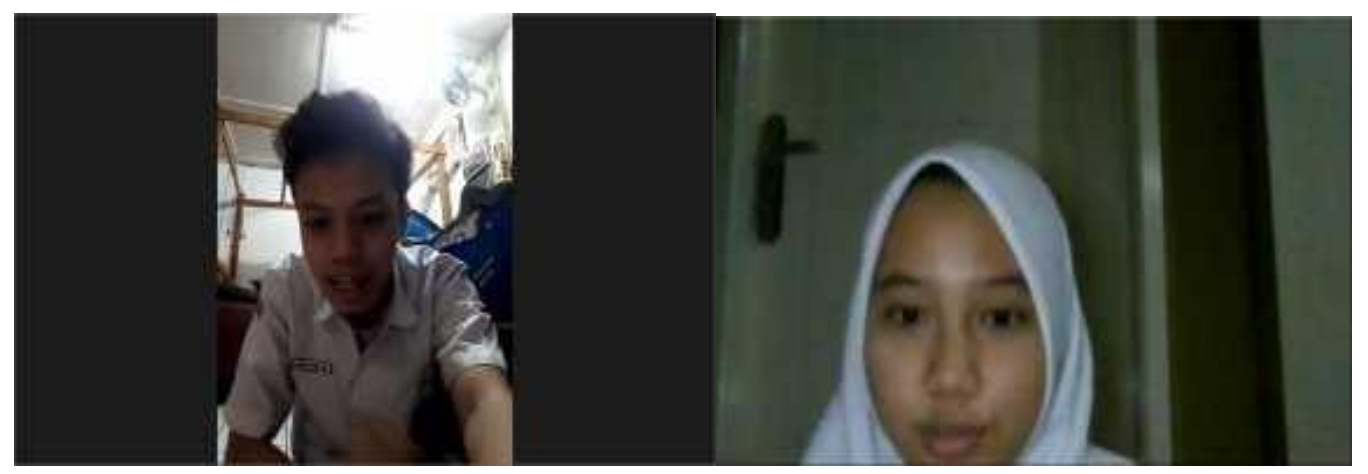

Figure 3. Students Discuss the Topic on Jumping Task

Based on observations during implementation, it is known that all groups rely on several reference sources to solve the problems of this "jumping" task, namely through books, and most dominantly via the internet (youtube/google). From google sources, besides finding the role of the buffer solution they wanted to find, students also found the components of the buffer solution directly, so that some groups immediately wrote it down on the student worksheets without trying to understand the relationship between the components of the buffer solution as a buffer in the examples they found. There was even a group that directly typed the answers on the LKPD sheet, because they used laptops in learning. The buffer component was only found in some groups, and the other groups took a long time to find a complete answer. Overall, jumping task activities did not raise students' creative thinking skills much compared to sharing task activities. This is because the tasks given do not require a lot of activity for students in completing assignments and students tend to work alone in finding answers, so the discussions are shorter so that they do not trigger the emergence of indicators of creative thinking skills. The following is a graph that shows the percentage of creative thinking skills in the jumping task activity.

Graph of the percentage of students' creative thinking skills in jumping task activities

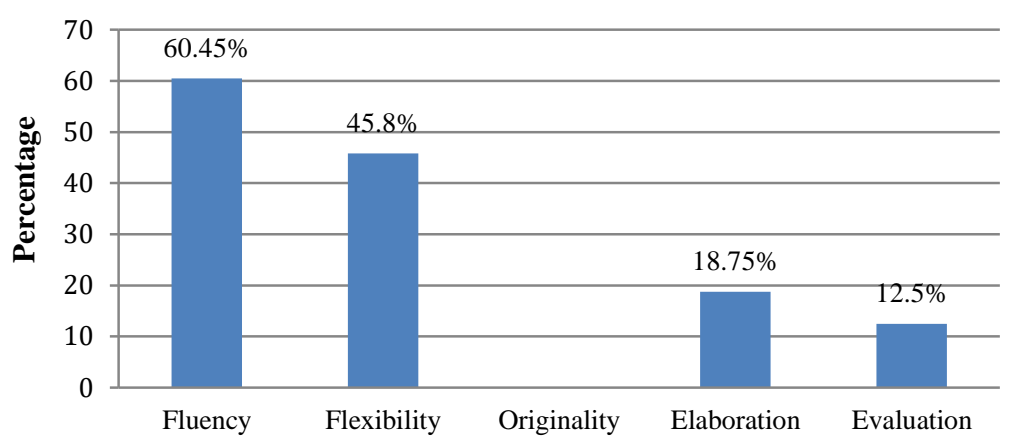

Aspect of Creative Thinking

Figure 4. Graph of the Percentage of Students' Creative Thinking Skills in Jumping Task Activities 
Figure 4 shows that of the 5 aspects of creative thinking skills identified only 4 aspects that appear during the jumping task activity, while the aspect that does not appear is the originality aspect. Aspects that appear in the jumping task include the fluency aspect with the highest percentage of $60.45 \%$, the flexibility aspect with the percentage of $45.8 \%$, the elaboration aspect with the percentage of $18.75 \%$, and the evaluation aspect with the percentage of $12.5 \%$. Based on the identification results from the jumping task activity, it shows that students' creative thinking skills that grow during learning activities are in accordance with the indicators and sub-indicators that appear during the learning process. Learning activities that foster students' creative thinking skills occur through the process of thinking how students find answers to the tasks given through all learning resources that can be accessed by students. Students collect data from the learning resources they have and then discuss to determine answers in solving problems/tasks. The creative thinking skills that appear in the jumping task activity are lower than in the sharing task activity. This is because the problems given are simpler, easier to find answers so that students can easily find answers to problems by accessing the internet.

In the fluency aspect, with a percentage of $60.5 \%$, it shows that more than half of the number of students who show creative thinking skills in the fluency aspect. It can be seen when students discuss examples of the role of buffer solutions, each student asks and answers each other, expressing opinions about the role of buffer solutions in blood and its $\mathrm{pH}$, other students ask how the $\mathrm{pH}$ is for medicine, photography, and the leather industry? Another student answered that for the $\mathrm{pH}$ of drugs to be adjusted to the $\mathrm{pH}$ of body fluids, injection drugs must be adjusted to the $\mathrm{pH}$ of the blood, meaning the $\mathrm{pH}$ is 7.35-7.45. In addition, they also discussed that a buffer solution to maintain the $\mathrm{pH}$ of body fluids so that the excretion of $\mathrm{H}^{+}$ions in the kidneys is not disturbed, namely dihydrogenphosphate acid $\left(\mathrm{H}_{2} \mathrm{PO}_{4}{ }^{-}\right)$with a monohydrogenphosphate base $\left(\mathrm{HPO}_{4}{ }^{2-}\right)$. In this discussion, it was seen that students were active in asking, answering, and expressing their ideas. This shows that students have been able to think fluently, generate thoughts with many ideas and provide suggestions in the learning process.

Furthermore, the flexible aspect grew by a percentage of $45.8 \%$. In determining the $\mathrm{pH}$ of the sample, students discuss the color changes that occur on the universal $\mathrm{pH}$ indicator paper. It can be seen that there are students who get different results from other students who are responded to by other students to give actual answers. This shows that students give consideration to a situation that is different from that given by others which is a flexible aspect. In the original aspect, it was identified that it did not appear in learning activities. This is because, in finding answers to the tasks given, students only look for answers from books or the internet, so that answers only come from sources found by students without any new ideas or ideas given by students. The absence of the original aspect of the jumping task activity indicates that there is still a lack of students' ability to express new thought or ideas that have not been thought of by others in solving problems. 
In the identified elaborative aspect, it grew by $18.7 \%$. In the learning process one of the students asked how the $\mathrm{pH}$ is for medicine, photography, and the skin industry, one of the students answered that for the $\mathrm{pH}$ of drugs to be adjusted to the $\mathrm{pH}$ of body fluids, injectable drugs must be adjusted to the $\mathrm{pH}$ of the blood, meaning the $\mathrm{pH}$ is 7.35-7.45. This shows that students are able to find a deeper meaning to answers or problem solving by taking detailed steps from the answers that students have found. Furthermore, in the evaluation aspect, which grew by a percentage of $12.5 \%$. It show that creative thinking skills, namely determining the benchmark for assessing whether a statement is true, a healthy plan or a wise action. This happened when students discussed the answers they found about the role of buffer solutions, and one of the students asked, "but I don't understand what carbonate buffer solution, hemoglobin buffer solution, and phosphate buffer solution are". Here it can be seen from the existing problems, students analyze and try to understand and ask critically in solving existing problems. This shows that learning to cultivate creative thinking skills in the aspect of evaluative thinking is quite difficult.

\section{Conclusion}

Based on the results of research and data analysis, it can be concluded that the implementation of sharing and jumping tasks learning can foster students' creative thinking skills. In the sharing task, all aspects of creative thinking skills emerged during the learning process, namely in the aspects of fluent thinking, flexible thinking, original thinking, elaborative thinking, and evaluative thinking. Meanwhile, in the jumping task, there is one aspect that does not appear, namely the aspect of original thinking. The implementation of sharing \& jumping task learning has implications for the learning process, namely encouraging students to be more active in the learning process, training students to interact and work together, and providing meaningful learning for students.

\section{Acknowledgment}

Thanks to Mr. Dr. rer nat Asep Supriatna, M.Si, Mr. Prof. Dr. Nahadi, M.Pd., M.Si, and Mr. Sumar Hendayana, Ph.D who has provided guidance for this research. The author would also like to thank the chemistry teacher, observer, as well as the XI.1 class students who have helped the researcher in conducting the research.

\section{References}

Aldig, E., \& Arseven, A. (2017). The Contribution of Learning Outcomes for Listening to Creative Thinking Skills. Journal of Education and Learning, 6(3), 41-53.

Amabile, T. M., Collins, M., Conti, R., \& Phillips, E. (1996). Creativity in context. Update to the social psychology of creativity. Boulder, Colorado. 
Westview Press Inc.

Arani, M. R. S. (2017). Raising the quality of teaching through kyouzai kenkyuuthe study of teaching materials. International Journal for Lesson and Learning Studies, 6(1), 10-26.

Barkley, E. F., Cross, K. P., \& Major, C. H. (2014). Collaborative learning techniques: A handbook for college faculty. John Wiley \& Sons.

Basarmak, U. (2019). The Effect of Digital Teaching Material (Public Service Ad) Development Process on Preservice Teachers' Creative Thinking Skills. Malaysian Online Journal of Educational Technology, 7(4), 126-144.

Birgili, B. (2015). Creative and critical thinking skills in problem-based learning environments. Journal of Gifted Education and Creativity, 2(2), 71-80.

Cahyani, M. D. (2017). Pembelajaran kolaboratif sharing task dan jumping task pada topik rumus empiris dan rumus molekul berdasarkan hambatan belajar siswa dan refleksi diri guru. Universitas Pendidikan Indonesia.

Cenberci, S. (2018). The Investigation of the Creative Thinking Tendency of Prospective Mathematics Teachers in Terms of Different Variables. Journal of Education and Training Studies, 6(9), 78-85.

Damayanti, H. T., \& Sumardi, S. (2018). Mathematical creative thinking ability of junior high school students in solving open-ended problem. Journal of Research and Advances in Mathematics Education, 3(1), 36-45.

Dillenbourg, P. (1999). Collaborative learning: Cognitive and computational approaches. advances in learning and instruction series. ERIC.

Eragamreddy, N. (2013). Teaching creative thinking skills. International Journal of English Language \& Translation Studies, 1(2), 124-145.

Forrester, A., Sobester, A., \& Keane, A. (2008). Engineering design via surrogate modelling: a practical guide. John Wiley \& Sons.

Habibi, M., Jumadi, J., Gummah, S., Ahzan, S., \& Prasetya, D. S. B. (2020). Project brief effects on creative thinking skills among low-ability preservice physics teachers. Int. J. Eval. \& Res. Educ. Vol, 9(2), 415-420.

Hadzigeorgiou, Y., Fokialis, P., \& Kabouropoulou, M. (2012). Thinking about creativity in science education. Creative Education, 3(05), 603.

Hendayana, S., \& Hidayat, A. (2013). Developing tools for analyzing of classroom interaction: Does it student-centered or teacher-centered lesson. Bandung: PPT Seminar International MSCEIS. UPI.

Johnson, D. W., \& Johnson, F. P. (1991). Joining together: Group theory and group skills. Prentice-Hall, Inc.

Kacan, S. D. (2015). A situational study for the identification of pre-service science teachers' creatıve thinking and creatıve scientıfic thinkıng skills. Journal of Education and Practice, 6(27), 82-86.

Koray, Ö., \& Köksal, M. S. (2009). The effect of creative and critical thinking based laboratory applications on creative and logical thinking abilities of prospective teachers. Asia-Pacific Forum on Science Learning \& Teaching, 10(1).

Krulik, S., \& Rudnick, J. A. (1995). The New Sourcebook for Teaching Reasoning and Problem Solving in Elementary School. A Longwood Professional Book. ERIC.

Kumdang, P., Kijkuakul, S., \& Chaiyasith, W. C. (2018). An Action Research on Enhancing Grade 10 Student Creative Thinking Skills Using Argument- 
Driven Inquiry Model in the Topic of Chemical Environment. Journal of Science Learning, 2(1), 9-13.

Kutlu, N., \& Gökdere, M. (2015). The effect of purdue model based science teaching on creative thinking. International Journal of Education and Research, 3(3), 589-600.

Munandar, U. (1992). Perkembangan kreativitas anak berbakat. Jakarta: Rineka Cipta.

Munandar, U. (1999). Perkembangan kreativitas anak berbakat. Jakarta: Rineka Cipta.

Northcott, B. (n.d.). Milliszewska., \& Dakich, E. 2007. ICT for Inspiring Creative Thinking. Proceeding Ascilite Singapore.

Perdana, R., \& Rudibyani, R. B. (2020). The Effectiveness of Inquiry Social Complexity to Improving Critical and Creative Thinking Skills of Senior High School Students. International Journal of Instruction, 13(4), 477490.

Potur, A. A., \& Barkul, O. (2009). Gender and creative thinking in education: A theoretical and experimental overview. A| Z ITU Journal of Faculty of Architecture, 6(2), 44-57.

Rahardjanto, A. (2019). Hybrid-PjBL: Learning Outcomes, Creative Thinking Skills, and Learning Motivation of Preservice Teacher. International Journal of Instruction, 12(2), 179-192.

Rajović, R., Gojkov-Rajić, A., \& Stojanović, A. (2017). preschool teacher assessment of the NTC program reach: Encouraging creative elements of thinking. Istraživanja u Pedagogiji, 7(2), 265-282.

Risnawati, R., \& Saadi, P. (2017). Meningkatkan Kemampuan Berpikir kReatif dan Hasil Belajar Melalui Model Pembelajaran Creative Problem Solving (CPS) pada Materi Larutan Penyangga. Quantum: Jurnal Inovasi Pendidikan Sains, 7(2), 127-134.

Sato, M. (2014). Presentasi Seminar Lesson Study. Universitas Pendidikan Indonesia, Bandung.

Sriwongchai, A., Jantharajit, N., \& Chookhampaeng, S. (2015). Developing the Mathematics Learning Management Model for Improving Creative Thinking in Thailand. International Education Studies, 8(11), 77-87.

Sternberg, R. J. (2003). Creative thinking in the classroom. Scandinavian Journal of Educational Research, 47(3), 325-338.

Syahrin, A., SUWIGNYO, H., \& PRIYATNI, E. T. (2019). Creative thinking patterns in student's scientific works. Eurasian Journal of Educational Research, 19(81), 21-36.

Tandiseru, S. R. (2015). The Effectiveness of Local Culture-Based Mathematical Heuristic-KR Learning towards Enhancing Student's Creative Thinking Skill. Journal of Education and Practice, 6(12), 74-81.

Widiarta, I. P., Suastra, I. W., \& Suswandi, I. (2017). Efektivitas Collaborative Learning Dalam Meningkatkan Kemampuan Berpikir Kreatif Siswa SMA. Jurnal Pendidikan Fisika Undiksha, 7(2), 204-213. 
Wijaya, E. Y., Sudjimat, D. A., \& Nyoto, A. (2016). Transformasi Pendidikan Abad 21 Sebagai Tuntutan. Jurnal Pendidikan, 1, 263-278.

How to cite this article:

Zestia, W., Supriatna, A., \& Nahadi. (2022). Implementation of Sharing \& Jumping Tasks Learning to Foster Students' Creative Thinking Skills in Buffer Solution. Journal of Educational Sciences, 6(1), 11-23. 